\title{
A Perspective on Arkansas Basin and Ozark Highland Prehistory
}

\section{J. Daniel Rogers}

Department of Anthropology National Museum of Natural History Smithsonian Institution

Follow this and additional works at: https://scholarworks.sfasu.edu/ita

Part of the American Material Culture Commons, Archaeological Anthropology Commons, Environmental Studies Commons, Other American Studies Commons, Other Arts and Humanities Commons, Other History of Art, Architecture, and Archaeology Commons, and the United States History Commons

Tell us how this article helped you.

This Article is brought to you for free and open access by the Center for Regional Heritage Research at SFA ScholarWorks. It has been accepted for inclusion in Index of Texas Archaeology: Open Access Gray Literature from the Lone Star State by an authorized editor of SFA ScholarWorks. For more information, please contact cdsscholarworks@sfasu.edu. 


\section{A Perspective on Arkansas Basin and Ozark Highland Prehistory}

Creative Commons License

(c) (i) (8)

This work is licensed under a Creative Commons Attribution-NonCommercial 4.0 International License 


\title{
A PERSPECTIVE ON ARKANSAS BASIN AND OZARK HIGHLAND PREHISTORY
}

\author{
J. Daniel Rogers \\ Department of Anthropology \\ National Museum of Natural History \\ Smithsonian Institution
}

It is, from time to time, valuable to reassess and perhaps shed new light on long-held perspectives. In "The 'Northern Caddoan Area' was not Caddoan," Frank Schambach (1990) provides a provocative reinterpretation of the archaeology of the Arkansas Basin and Ozark Highland regions of Oklahoma, Arkansas, and Missouri. While certain comments in this paper have merit and deserve deeper consideration, the central theme and supporting arguments are severely flawed, both from conceptual and data points of view.

Schambach's central argument is that there were no Caddoans in the Arkansas Basin and Ozark Highlands north of Spiro. To make this point he asserts that the only Caddoan site north of the Ouachita Mountains is the Brown Mound group at Spiro. All the other sites in the region, including the Craig Mound group at Spiro, are not Caddoan, but are instead a currently undefined Mississippian manifestation. Schambach's scenario goes something like this: Mississippians moved up the Arkansas River valley in the early Mississippian Period (presumably in the Harlan Phase, A.D. 850-1250), through western Arkansas to eastern Oklahoma where they displaced the Caddoans living at the Brown Mound group. The Caddoans moved back south to the Ouachita Mountains. The Mississippians, including "people of the Plum Bayou culture. . . the Spiro phase [A.D. 1250-1450]" then built Craig Mound at Spiro while possibly operating a trade system "to supply buffalo meat and hides to the rapidly growing and increasingly protein poor and clothing poor Mississippian populations. . .." to the east (p. 3). Later, the Mississippians, who were probably ancestral Tunica, retreated back down the Arkansas River "to south of Dardenelle, where De Soto encountered them in 1541 (p. 4)". The Caddoans then returned to the Spiro area to become the people of the Fort Coffee Phase (A.D. 1450-1500s). This sequence of events is a fascinating reinterpretation of regional culture history, unfortunately it falls flat when confronted by either contemporary theory or the data.

The basis for Schambach's argument is a two-pronged theoretical orientation relying on geographical determinism and the notion that Mississippians and Caddoans are distinctive groups of people with their own set of unique material "traits". These are perspectives I expressly reject and which are marginal given the advances of the last 30 years of American archaeology. The role of geographical determinism in Schambach's argument is evident in his insistence that the Ozark Highlands, the Arkansas River Valley, and the Ouachita Mountains each had a distinct culture history apparently relating to ethnically identifiable groups of people (p. 3, also see Schambach 1988, 1990). It would be too tedious to recount the intellectual history of geographical or ecological determinism; instead, suffice it to say that such orientations have been 
replaced by culture ecology, ecological functionalism, and related perspectives, each making use of the idea of adaptation, but without reliance on strict biogeographical boundaries (e.g., Wyckoff 1980).

Although Schambach uses the terms "Mississippian" and "Caddoan" to mean variously, a time period, a cultural tradition, or a group of people, the latter usage is the one least in accord with recent evidence. To imagine the migration of Mississippians up the Arkansas River to Spiro and beyond, clearly implies a connection with the old Mississippian "heartland" and expansion concepts. Even in the 1950s Phillips, Ford, and Griffin (1951:451) suggested that the Mississippian cultural tradition developed in a number of localities almost simultaneously. Now, increasing evidence from many parts of the eastern United States has helped to confirm their viewpoint. Migration is simply not a good explanation for the spread of the Mississippian cultural tradition into the Arkansas Basin and Ozark Highlands (Peebles 1990:26; Smith 1984). If the Craig Mound group were built by a group of ethnically Mississippian peoples, then the explanation would depend on migration and the site-unit intrusion argument similar to the classic, but poorly founded, example offered by Willey for the Macon Plateau (1953:370-372). Migrations did sometimes occur in prehistory (Rouse 1986), but Spiro is not one of those cases.

Schambach's argument contains several inaccuracies that, taken together, provide a sound case for rejection of his reinterpretation. I will address a few of these problems before concluding with a brief statement of what constitutes a far more likely scenario for the prehistory of the Arkansas Basin and Ozark Highlands. One statement that is particularly inaccurate has to do with Schambach's attempt to show that the concept of a Northern Caddoan Area has no legitimate basis. He states that Orr (1946) defined Spiro as Caddo simply because Swanton (1932) included eastern Oklahoma when he drew a line around the Caddoan area. A subtle, but important point here is that Orr never used the word Caddo, as Schambach states; instead, Orr used the word Caddoan as a means of acknowledging differences between the regions. Furthermore, Orr $(1946: 249,250,253,255)$ uses the information available to him from Harrington (1920), Jackson (1934), Sayles (1935), and Krieger (1945) to discuss the connections between Spiro (and other sites in the Arkansas Basin and Ozark Highlands) and several sites in the Red River region. Orr was not blindly following Swanton's suggestion, nor was he just using pottery types to define these relationships--many artifact categories and features enter into the discussion. Likewise, it is inaccurate to attribute the definition of a north-south link to Orr alone. Well before the time of Orr's writing the idea of a Caddoan presence in the Arkansas Basin and Ozark Highlands was widely accepted (e.g., Thoburn 1931:76). Several archaeologists in the 1940s, most notably Krieger (1944, 1946:Map 1, Fig. 26), also defined and refined the attributes that connected the two areas. Given new data, some of the relationships discussed in the 1930s and 1940s would not stand up under scrutiny today; but, even so, Schambach's attempt to trivialize the development of a north-south link is far from convincing.

The bulk of Schambach's paper centers on reinterpreting the Spiro site. As stated above, he describes the Brown Mound group as Caddo (not just Caddoan, but specifically Caddo) and the Craig Mound group as Mississippian. It is not possible to separate these two areas of the site, nor is it possible to isolate the Brown Mound group from the many other Harlan Phase mound centers and habitation sites throughout the Arkansas Basin and Ozark Highlands. There is no material culture or chronological distinction, as Schambach argues. 
At Spiro, contrary to Schambach's claim, there is ample material continuity to link the upper and lower portions of the site. All the non-mound buildings, whether upland or lowland, are very similar. The buildings are square, with four center-posts, an extended entryway, and individually set wall-post construction. They are found scattered across the site, but especially on the lower areas (Brown 1966:125-143). Schambach argues that the clay- and grog-tempered pottery found in the Brown Mound group defines these mounds as Caddo and separates them from the Mississippian shell-tempered pottery using people who built the mounds on the bottomlands at Spiro and at other sites like Harlan. However, the buildings on the bottomlands do not contain shell-tempered pottery, they contain grog-tempered Williams Plain (over 92\%), and grog-tempered pottery also predominates in the early levels and burials of Craig Mound (Brown 1966:88-89, 111-114, Brown 1971:197, 200; Rogers 1982:44, 162-170). Rather than evidence for occupation by two distinct ethnic groups, Spiro presents substantial continuity through time, with grog-tempered ceramics predominately early and shell-tempered ceramics predominately late. To verify this it is instructive to look not just at Spiro, but also at the numerous habitation sites in the immediate area. Rohrbaugh (1985:159-160) provides important evidence for continuity by pointing out the continuation of particular pottery types through the Harlan, Spiro, and Fort Coffee Phases.

Schambach attempts to draw a distinction between the Brown Mound group and other Harlan Phase sites like Harlan (Bell 1972) by noting differences in house mounds and pottery types. The differences he notes are designed to confirm chronological and cultural distinctions, however, the radiocarbon dates from the Brown Mound group and the Harlan site show contemporaneity (Bell 1972:253-258; Brown 1967; Rogers 1980, 1982). As for the house mounds, the architecture and artifacts (for instance from House Mounds 4 and 5) from the Brown Mound group are virtually identical to the architecture and associated artifacts from the Harlan site (Bell 1972:164, 165, 220; Brown 1966:117; Rogers 1982:45-46). There are also a number of similarities in the architecture associated with all types of mounds throughout the Arkansas Basin and Ozark Highlands (e.g., Kay 1990; Kay et al. 1989; Muto 1978; Rogers 1982:49-91). Schambach also argues that the buildings at Harlan were "scrupulously cleaned mortuaries" while those in the Brown Mound group contain domestic debris (p. 4). This is a very problematic statement considering that the buildings at both sites produced very little debris (Bell 1972:221; Brown 1966:115). Only House Mound 5 produced much artifactual debris, but this is the only one in which the fill was screened (Rogers 1980, 1982).

Even more important to Schambach's argument than the house mounds is the type of pottery present at the Brown Mound group and at the Harlan site. He contends that the former is characterized by grog-tempered pottery and the latter by shell-tempered pottery, like Woodward Plain. This is simply not true. It is only a matter of reviewing Bell's Table 14 (1972:226) to see that shell-tempering is not common at the Harlan site and Woodward Plain is only about $8 \%$ of the total sherd count. The reason that there is any Woodward Plain at all is that it increases slightly in the latest burials, which are late Harlan Phase and show some of the characteristics of the subsequent Spiro Phase. Rather that severing the links between the Brown Mound group and the Harlan site the evidence provides one of the strongest links between any two sites anywhere and provides good evidence for cultural continuity.

A far more parsimonious culture history for the Ozark Highlands and Arkansas Basin, one that does not require a complex sequence of migrations, is the interpretation currently in use 
(see relevant chapters in Bell [1984] and Rogers et al. [1989]). The late prehistory begins with hunting and gathering groups of the Fourche Maline Phase (ca. 300 B.C.-A.D. 850) scattered across western Arkansas and eastern Oklahoma. These groups began using pottery and cultivating native plants around A.D. 500 to A.D. 700 . Sometime between about A.D. 800 and A.D. 900 the descendants of Fourche Maline Phase peoples participated in the development of ranked societies known to us as the Harlan Phase (A.D. 850-1250), including the establishment of mound centers, settlement hierarchies, substantial public architecture, hierarchical burial treatments, and increased cultivation of maize. These developments probably originated through a variety of interactions with similar groups to the east and south and are linked with the emergence of the Mississippian over a vast portion of the eastern woodlands (e.g., Early 1990; Smith 1990). Exchange of exotic high status goods such as marine shell and copper was probably important to this developmental process (Rogers 1990). Subsequent cultural developments in the Spiro Phase (A.D. 1250-1450) continued the trend toward further cultural elaboration, although there is yet no evidence that maize was the dominant crop. At Spiro very elaborate burials occuir in Craig Mound with less ornate, but similar versions in contemporary mound sites like Norman (Finkelstein 1940; Rogers et al. 1990). The Fort Coffee Phase (A.D. $1450-1500$ s) marks a major departure from the elaborations of the Harlan and Spiro Phases. As in several regions, mound construction and use cease and evidence for a hierarchical social system declines.

While there are other trouble areas in Schambach's analysis, the one primary point that remains is the question of whether there were Caddoans in the Ozark Highlands and Arkansas Basin. There is no evidence that there were people in the region who were the direct ancestors of the historic Caddo, but no one in recent times seriously argues this. Very few archaeologists working in the Ozark Highlands and the Arkansas Basin use the term Caddo at all, instead Caddoan is preferred, to acknowledge similarities between the north and the south that are more than just a trade link. Ultimately there is little point in continuing what amounts to a debate over terminology that does not advance useful analysis. In part, Schambach's reanalysis seems to be responding to the impression that the prehistory of the Spiro site has received too much attention because of its anomalous artifact hoards, which are, of course, not representative of Caddoan prehistory. These are useful observations, and while he seeks to deemphasize Spiro's role, he in fact hinges his entire argument on Spiro. This aside, Schambach's idea that Spiro had little connection with or influence over other sites in the region is not supportable. Evidence for hierarchical settlement systems with similar patterns of mortuary treatment are part of the evidence for regional interactions (Brown et al. 1978; Rogers 1983). Spiro probably did not exert authoritative control over this vast region, but there are strong connections that provide an important grounding for future research.

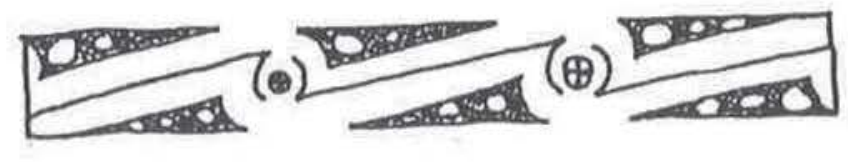




\section{References Cited}

Bell, Robert E.

1972 The Harlan Site, Ck-6, A Prehistoric Mound Center in Cherokee County, Eastern Oklahoma. Memoir of the Oklahoma Anthropological Society 2. Oklahoma City.

Bell, Robert E. (editor)

1984 Prehistory of Oklahoma. Academic Press, New York.

Brown, James A.

1966 Spiro Studies, Vol. 1, Description of the Mound Group. First Part of the Second. Annual Report of Caddoan Archaeology--Spiro Focus Research. University of Oklahoma Research Institute, Norman, Oklahoma.

1967 New Radiocarbon Dates from the Spiro Site. Bulletin of the Oklahoma Anthropological Society 15:77-80.

1971 Spiro Studies, Vol. 3, Pottery Vessels. First Part of the Third Annual Report of Caddoan Archaeology--Spiro Focus Research. University of Oklahoma Research Institute, Norman, Oklahoma.

Brown, James A., Robert E. Bell and Don G. Wyckoff

1978 Caddoan Settlement Patterns in the Arkansas River Drainage. In Mississippi Settlement Patterns, edited by Bruce D. Smith, pp. 169-200. Academic Press, New York.

Early, Ann

1990 Look to the Southern Hills: Late Prehistoric Relationships Between the Arkansas River Valley and Ouachita Mountains of Arkansas. Paper presented at the 55th Annual Meeting of the Society for American Archaeology, Las Vegas, Nevada.

Finkelstein, J. Joe

1940 The Norman Site Excavations near Wagoner, Oklahoma. The Oklahoma Prehistorian 3(3):2-15.

Harrington, M. R.

1920 Certain Caddo Sites in Arkansas. Indian Notes and Monographs 10. Museum of the American Indian, New York.

Jackson, A. T.

1934 Types of East Texas Pottery. Bulletin of the Texas Archeological and Paleontological Society 6: 38-57. 
Kay, Marvin

1990 A Regional Assessment of Huntsville Mounds in the Western Ozark Highland. Paper presented at the 55th Annual Meeting of the Society for American Archaeology, Las Vegas, Nevada.

Kay, Marvin, George Sabo, III, and Ralph J. Merletti

1989 Late Prehistoric Settlement Patterning: A View from Three Caddoan

Civic-Ceremonial Centers in Northwest Arkansas. In Contributions to Spiro

Archaeology: Mound Excavations and Regional Perspectives, edited by J. Daniel

Rogers, Don G. Wyckoff and Dennis A. Peterson, pp. 129-157. Studies in

Oklahoma's Past 16. Oklahoma Archeological Survey, Norman.

Krieger, Alex D.

1944 Archaeological Horizons in the Caddoan Area. Revista Mexicana de Estudios

Historicos 7:154-156.

1945 An Inquiry into Supposed Mexican Influence on a Prehistoric 'Cult' in the Southern United States. American Anthropologist 47:483-515.

1946 Culture Complexes and Chronology in Northern Texas, with Extension of Pueblo Datings to the Mississippi Valley. University of Texas Publication 4640. Austin.

Muto, Guy R.

1978 The Habiukut of Eastern Oklahoma: Parris Mound Part 1, Phase 1, an

Archaeological Report. Series in Anthropology 3. Oklahoma Historical Society, Oklahoma City.

Orr, Kenneth G.

1946 The Archaeological Situation at Spiro, Oklahoma: A Preliminary Report. American Antiquity 11:228-256.

Peebles, Christopher S.

1990 From History to Hermeneutics: The Place of Theory in the Later Prehistory of the Southeast. Southeastern Archaeology 9:23-34.

Phillips, Philip, James A. Ford, and James B. Griffin

1951 Archaeological Survey in the Lower Mississippi Alluvial Valley, 1940-1947. Papers of the Peabody Museum of Archaeology and Ethnology 25. Harvard University, Cambridge.

Rogers, J. Daniel

1980 Spiro Archaeology: 1979 Excavations. Studies in Oklahoma's Past 6. Oklahoma Archeological Survey, Norman. 
1982 Spiro Archaeology: 1980 Research. Studies in Oklahoma's Past 9. Oklahoma Archaeological Survey, Norman.

1983 Social Ranking and Change in the Harlan and Spiro Phases of Eastern Oklahoma. In Southeastern Natives and Their Pasts: Papers Honoring Dr. Robert E. Bell, edited by Don G. Wyckoff and Jack L. Hofman, pp. 17-128. Studies in Oklahoma's Past 11. Oklahoma Archeological Survey, Norman.

1990 Patterns of Change on the Western Margin of the Southeast, A.D. 600-900. In Stability, Transformation, and Interaction: Late Woodland in the Greater Southeast, edited by Michael Nassaney and Charles Cobb. Plenum Press, New York, in press.

Rogers, J. Daniel, Don G. Wyckoff, and Dennis A. Peterson (editors)

1989 Contributions to Spiro Archeology: Mound Excavations and Regional Perspectives. Studies in Oklahoma's Past 16. Oklahoma Archeological Survey, Norman.

Rogers, J. Daniel, Lois E. Albert, and Karen M. Dohm

1990 The Norman Site and the Organization of Mound sites in the Ozark Highlands and Arkansas Basin. Ms. on file, Department of Anthropology, Smithsonian Institution.

Rohrbaugh, Charles L.

1985 The Subdivision of Spiro Phase. Midcontinental Journal of Archaeology 10:155-170.

Rouse, Irving

1986 Migrations in Prehistory: Inferring Population Movement from Cultural Remains. Yale University Press, New Haven.

Sayles, G. I., Jr.

1935 An Archaeological Survey of Texas. Medallion Papers, Gila Pueblo 17. Globe, Arizona.

Schambach, Frank F.

1988 The Archaeology of Oklahoma. Quarterly Review of Archaeology 9:5-9.

1990 The "Northern Caddoan Area" was not Caddoan. Caddoan Archeology

Smith, Bruce D.

1984 Mississippian Expansion: Tracing the Historical Development of an Explanatory Model. Southeastern Archaeology 3:13-32.

(editor)

Mississippian Emergence. Smithsonian Institution Press, Washington, D.C. 
Swanton, John R.

1932 Archaeological Culture Areas. Paper presented at the Conference on Southern Prehistory, National Research Council, Washington, D.C.

Thoburn, Joseph B.

1931 The Prehistoric Cultures of Oklahoma. In Archaeology of the Arkansas River Valley, edited by Warren King Moorehead, pp. 53-82. Phillips Academy, Andover, Massachusetts.

Willey, Gordon R.

1953 A Pattern of Diffusion-Acculturation. Southwestern Journal of Anthropology 9:369-383.

Wyckoff, Don G.

1980 Caddoan Adaptive Strategies in the Arkansas Basin. Eastern Oklahoma. Ph.D. dissertation, Washington State University. University Microfilms, Ann Arbor.

\section{PUBLICATIONS}

\section{Books and Periodicals}

Benavides, A.

1989 The Bexar Archives (1717-1836): A Name Guide. University of Texas Press. 1171 pp.

Dunnell, R.C.

1990 The Role of the Southeast in American Archaeology. Southeastern Archaeology 9(1):11-22.

Dye, D.H. and C.A. Cox (editors)

1990 Towns and Temples along the Mississippi. University of Alabama Press. $245 \mathrm{pp}$.

This volume includes an article by M.P. Hoffman on the Terminal Mississippian Period and the emergence of the Quapaw, and I.W. Brown's article on an archaeological perspective on the Historic Native American peoples of the Lower Mississippi Valley.

Hobhouse, $\mathrm{H}$.

1991 Seeds of Change. Smithsonian Institution Press, Washington, D.C.

Hunter, D.G.

1990 The Apalachee on Red River, 1763-1834: An Ethnohistory and Summary of Archaeological Testing at the Zimmerman Hill Site, Rapides Parish, Louisiana. Louisiana Archaeology 12:7-127.

Jeter, Marvin D.

1990 Edward Palmer's Arkansaw Mounds. University of Arkansas Press, Fayetteville. 